\begin{tabular}{|c|c|c|}
\hline Beitr. Ent. & Keltern & ISSN 0005-805X \\
\hline $\mathbf{5 4}(2004) 1$ & S. $107-125$ & 28.05 .2004 \\
\hline
\end{tabular}

\title{
Seasonal head dimorphism and taxonomy of some European species of Aprosthema
}

\author{
(Hymenoptera: Symphyta: Argidae)
}

\author{
VELI VIKBERG
}

With 11 figures

\section{Summary}

Head shape has been regarded as an important character distinguishing species in the sterictiphorine genus Aprosthema KONOw (Argidae). Oviposition experiments on southern Finnish females of A. melanurum (KLUG, 1814) on Latbyrus pratensis L. (Fabaceae) showed that the overwintered female (spring generation) has a long head with temples parallel or broadening posteriorly and a shorter flagellum, whereas the female (and male) of the summer generation has a short head with strongly narrowing temples and a longer flagellum. The thick winter cocoons are in the ground. The thin soft summer cocoons are formed on the food plant or some other nearby plant, and the emerging adult does not need strong muscles to open the cocoon. A similar head shape dimorphism is found in the two generations of Aprosthema fusicorne (THOMSON, 1871) feeding on Vicia cracca L. (Fabaceae), and of A. intermedium (ZADDACH, 1864) = A. byalinoptertm CONDE, 1934, syn. nov. feeding on Latbyrus vernus (L.) BERNH. These are the first observations of seasonal head dimorphism in sawflies. Lectotypes are designated for Hyloioma melanura KLUG and Aprostbema byalinopterum CONDE. A key is presented to the 5 species of Aprosthema examined. Three species of Aprosthema are reported from England.

\section{Zusammenfassung}

Die Kopfform wurde bislang als wichtiges Merkmal für die Unterscheidung der Arten des SterictiphorinenGenus Aprosthema KONOW (Argidae) angesehen. Eiablage-Experimente mit südfinnischen Weibchen von Aprosthema melanurum (KLUG, 1814) an Lathyrus pratensis L. (Fabaceae) zeigten, dass überwinterte Weibchen (Frühlingsgeneration) einen langen Kopf mit parallelen oder erweiterten Schläfen und ein kürzeres Flagellum haben, während die Weibchen (und Männchen) der Sommergeneration stark verengte Schläfen und ein längeres Flagellum aufweisen. Die kräftigen Winterkokons befinden sich in der Erde. Die dünnen, schwach gebauten Sommerkokons hingegen werden an der Futterpflanze oder einer nebenstehenden anderen Pflanze gebildet. Zum Öffnen dieser Kokons benötigen die Imagines keine starken Muskeln. Ein ähnlicher Dimorphismus der Kopfform wurde auch bei den zwei Generationen des an. Vicia cracca L. (Fabaceae) lebenden Aprostbema fusicorne (THONSON, 1871) sowie dem an Latbyrus vernus (L.) BERNH. lebenden $A$. intermedium (ZADDACH, 1864) [ = A. byalinopterum CONDE, 1934, syn. nov.)] nachgewiesen. Es handelt sich hierbei um die ersten Nachweise von saisonalem Kopfdimorphismus bei Pflanzenwespen. Lectotypen wurden für Hylotoma melanura KLUG und Aprostbema byalinopterum CONDE festgelegt. Ein Bestimmungsschlüssel für die 5 untersuchten Aprosthema-Arten wird vorgelegt. 3 Aprosthema-Arten werden für England nachgewiesen. 


\section{Introduction}

The species of Aprosthema are mostly rare and seldom collected (ENSLIN 1917), and many of them have been described on the basis of one or few specimens. The biology of rather few species is known but all reared species have larvae feeding on leguminous plants (Fabaceae). The head form has been regarded as an important character to distinguish between the species of the genus (THOMSON 1871, KONOW 1892, ENSLIN 1917, CONDE 1934a, GUSSAKOVSKI 1935, ZHELOCHOVTSEV 1988, and VIITASAARI 1990). However, this paper aims to show that the head form is different between the specimens of the spring or overwintered and summer generations of the same species in three European species. Notes on the taxonomy of some European species of Aprosthema are given.

\section{Material and methods}

In order to correctly identify the specimens of Aprosthema KonOw many name bearing type specimens were examined, including the following five:

Hylotoma brevicornis FALLÉN, 1808: 44, ․ Syntype(s): an jure? Capta in Vestrogothnia. Lectotype female (in coll. FALLÉN, Zoological Museum, University of Lund) designated by VITTASAARI et al. (1998: 143). According to THOMSON (1871:44) the type female was found near Esperöd in Skåne.

Hylotoma melanura KLUG, 1814: 303, o. Syntype(s) from Harz, Germany. Lectotype female hereby designated, in order to fix the use of the nominal taxon, in coll. KLUG in Zoological Museum, Berlin labelled: 1) 13697 [printed label]; 2) Zool. Mus. Berlin; 3) melanura [: stood as $H$. melanura in KLUG's collection]; 4) Lectotype + Hylotoma melanura KLUG, 1814; V. VIKBERG 2001; 5) Aprosthema melanumm (KLUG) o , summer form; det. V. Vikberg 2001.

Schizocera fusicornis THOMSON, 1871:46, ․ Syntypes: one female from Öland, Sweden found by Prof. Boheman. (The male mentioned in a Swedish note from Jemtland is not a syntype because its identity remained unclear to the author). Holotype female was found among the specimens in Naturhistoriska Riksmuseet, Stockholm, and it is labelled: 1) Oel; 2) Bhn; 3) Schizocera fusicornis [in Thomson's handwriting]; 4) Holotype † Aprosthema fusicorne (THOMSON, 1871), spring form; V. VIKBERG 2001; 5) Naturhistoriska Riksmuseet, Stockholm Loan no 22/99.

Aprosthema byalinopterum CONDE, 1934a: 22 (key), 25-28, \& o larva. Adult syntypes: Latvia, North of Viesite, in the state forest near Gerkani, 1 o 1 \% 28.5.1933, and one further female reared by letting the above female lay eggs on the leaflets of Latbyms vermus (L.) BERNH., the female emerged on 4 Feb, 1934. The reared female (in coll. DEI, Eberswalde) was examined: it had been eaten by dermestid larva, and only the left fore wing, tegula, pronotum and most of the mesonotum are left. As the only available syntype it is designated hereby as the lectotype of Aprostbema byalinopterum CONDE, in order to fix the nominal taxon. It is labelled: TYPE [red label]; VIESITE, GERGANI, versponnen 25.VI.1933, O. Conde 
leg. geschl. im Zimmer 4 Febr 1934. No. 336; Aprostbema byalinoptera CONDE Type No. 3071 ㅇ. The cocoon is pinned with the specimen; its dimensions are $9 \times 5 \times 5 \mathrm{~mm}$. It is double walled, brownish white, and the larval skin is inside. Characters of the lectotype: Fore wing $5.5 \mathrm{~mm}$ long, with costal cell infuscate, otherwise almost hyaline. Pterostigma (0.96 mm long, $0.45 \mathrm{~mm}$ wide) and veins dark brown, costa pale brown, $3.2 \mathrm{~mm}$ long. Short basal anal stump. Pronotum, tegula and mesonotum black. Two males of the summer generation reared on 14.7.1935 (now in coll. DEI, Eberswalde) and 25.7.1935 (now in NHM, London) from larvae on Latbyrus vernus in Suntaschi: Gerki, Latvia by $\mathrm{O}$. Conde were examined. Both bear the identification label: Aprosthema byalinoptera $\mathrm{O}$. CONDE, det. O. Conde. The first specimen also bears a label: Aprosthema melanura (KLUG), det. Muche 1972. CONDE (1934a) examined the female holotype of Schizocera intermedia ZADDACH, 1864 (p. 121) and compared it with his new species. According to him Aprosthema intermedium female had among others following characters: Wing clear, basally hardly yellowish. Temples in dorsal view strongly narrowing behind eyes, lateral vertex flat, without any furrow from lateral ocellus to eye. Head width $1.68 \mathrm{~mm}$, flagellum $1.31 \mathrm{~mm}$ long, maximally $0.205 \mathrm{~mm}$ wide, flagellum/head width 0.78 , flagellum: length/ width 6.4. The female of $A$. byalinopterum had hyaline wing, head width $1.72 \mathrm{~mm}$, flagellum only $1.07 \mathrm{~mm}$ long, maximum width $0.164 \mathrm{~mm}$, length/width 6.5 . Temples behind eyes parallel, lateral vertex with strong furrow. Thus these two species differed mainly by the head form and the length of the flagellum in female sex. However, the two reared males mentioned above have a head form similar to that of $A$. intermedium (Fig. 2f), and so the species are treated as synonymous. Specimens described as $A$. byalinopterum (CONDE) represent the spring generation of the older species $A$. intermedium (ZADDACH), syn. nov.

Aprosthema volgense GusSAKOVSKI, 1935: 304, 327, 438, 450, ㅇ. Syntypes: one female from Jaroslavl (Kokujev). Holotype female in coll. Zoological Institute, Sankt Peterburg is labelled; round golden yellow label [ $=$ type]; Jarosl.; coll. Kokujev; Aprosthema volgensis, sp. [n.] $\%$, Gussakovskij det. It is a female of the spring generation; the head in dorsal view (Fig. 2e). The species was correctly synonymized with $A$. byalinopterum CONDE by ZHELOCHOVTSEV (1988).

Field observations and rearings, including ovipositing experiments of Aprosthema melanurum (KLUG) were performed at two localities in southern Finland: Liperi (Kb), Honkalampi (Grid $27^{\circ} \mathrm{E} 694: 62$ ) in 1994, and Janakkala (Ta), Turenki (6761:371) in 2000 and 2001.

During the summer excursion of the Entomological Society of Finland at the beginning of July 1994 an isolated population of Aprosthema melanurum was found in Liperi associated with Latbyrus pratensis L. (Fabaceae). Several males and females with long head form were captured in nature. Females and males with short head form were reared from larvae feeding on Latbyrus or from thin, pale yellowish cocoons with double walls on Latbyrus or other plants nearby. Two ovipositing experiments were performed. A female with strong head form (no. 8/94 VV) captured on 4 July. Laid eggs on leaflets of Lathyrus pratensis on the evening of the same day. It took 50-75 seconds per egg. Larvae hatched on 8 July, their head was black. First moult was observed on morning of 10.7., second moult on 11.7. 
Third moult took place on 13.7.-14.7. The larvae of 4. instar eat besides leaflets also stems of Latbyrus. Fourth moult on 16.7. On 18.7.-19.7. two cocoons were constructed between leaves of Latbyrus, no extra moult occurred after feeding was completed. On 25.7. two males with short head form emerged.

Another ovipositing experiment $(8 \mathrm{~b} / 94)$ : one male and 4 females were reared from larvae on Latbyrus on 9.7.-10.7. All were put into large vessel with Latbyrus. On 10.7.11.7. females laid eggs through the margin of leaflet. One egg was laid singly, after that the female flew away from the food plant. Copula was not observed. The larvae grew well until 19.7 indoors, when fourth instar larvae were put into a net on a Lathyrus bush outside. On 25.7 they were inspected when I returned from Lapland. 21 full or almost full grown larvae were found but workers of Lasius niger L. had attacked them and injured them by biting. The larvae were put into alcohol.

The ovipositing experiments in Janakkala: on 15.5 .2000 a female was found on Latbyrus pratensis. She laid eggs on leaflets of Latbyrus, laying one egg took 55 seconds. 25-30 larvae emerged on 19.5.-20.5, they eat on the leaflet margin keeping body s-shaped. The second instar larvae got some acute disease and all died. They were briefly boiled and put into alcohol.

Next year I visited the same place on 27 May, and swept simultaneously two males and two females of $A$. melamurum on Latbyrus pratensis. The females with strong head form were used for ovipositing experiments (no. 6/01 and 7/01). On 27.5.-28.5. Vicia cracca and Latbyrus pratensis were offered to each of them.

Both laid eggs only on margins of leaflets and stipules of Latbyrus. Larvae hatched on 31 May, they moulted four times and part of larvae five times. On 9 June first small cocoons were found on the food plant. Males emerged from these on 16-17 June. Altogether 27 and 8 cocoons were found on 15 June. Female no. 6 gave 5 males and 20 females and female no. 7 gave 6 females, all progeny had the short weak head form.

Specimens of two generations of Aprosthema fusicome (THOMSON) from Finland: Pälkäne (Ta) (mostly 680:35) were studied and measured. The biology of the species has been studied there for many years by Jaakko K. Kangas and his collaborators (KANGAS 1985; as A. melanura and A. fusicornis). Specimens with both strong and weak head form of the species have been reared from larvae on Vicia cracca L. (Fabaceae). The specimens with a strong head form occur earlier in the season in the same places where the specimens with a weak head form are found later. All available specimens from Pälkäne were studied and measured. Flight periods are as follows: Females with stronger head ( $n=11$ ) were captured in June, except one on 27 May, 29 May, 3 July and 14 July each. Males with strong head $(n=7)$ were captured on 1.6.-17.6. Females with weaker head were found in the last half of July, except one on 14 July and one on 2 August. The males with weaker head were found on 15-24 July. Only one ovipositing experiment (no. 3/86 JK) has been carried out: the female with strong head found on 12.6.1986 laid eggs singly on the leaflets of Vicia cracca (she did not lay eggs on the offered Latbyrus pratensis), the prepupae overwintered and two males emerged in March 1987 (these males have a furrow on lateral vertex, but rather short, narrowing temples). Although there is no direct confirmation by an ovipositing experi- 
ment that the spring and summer generations belong to the same species, all indirect evidence strongly suggests it, especially when compared with the similar proven situation in Aprosthema melanurum. Further evidence is presented in Results (the similar structure of lancets and penis valves).

The sawfly specimens and dry prepared larvae were studied under a Leitz stereomicroscope at magnifications of $50 \mathrm{x}$ and $100 \mathrm{x}$; the light source was a halogen lamp of $12 \mathrm{~V} 20 \mathrm{~W}$ with a light beam width of 10 degrees. The light was diffused by placing a piece of thick $(0.2 \mathrm{~mm})$ tracing acetate near the specimen. Measurements and drawings were made using a grid of squares $(50 \times 50$, side $0.20 \mathrm{~mm}$ ) in one eyepiece. Some larvae in alcohol were treated with $\mathrm{KOH}$, and dissected body parts were put into polyviol 17 under a cover glass on a slide. The slide was examined with a compound mictoscope at magnifications up to $450 \mathrm{x}$; this made it possible to see very small setae (microsetae) and glandubae. Body part nomenclature is according to HUBER \& SHARKEY (1993) and VIITASAARI (2002).

Table 1. Size of specimens of Aprosthema melanurum (KLUG) and A. fusicome (THOMson). Length values: mean and range in $\mathrm{mm}$.

\begin{tabular}{|c|c|c|c|c|c|c|}
\hline Species, sex, locality & Body & Wing & Costa & $\begin{array}{l}\text { Costa/ } \\
\text { Wing }\end{array}$ & $\begin{array}{l}\text { Head } \\
\text { width }\end{array}$ & $\begin{array}{l}\text { Generation } \\
\text { (examined) }\end{array}$ \\
\hline melanurum o, Liperi & $\begin{array}{l}6.57 \\
6.3-7.1\end{array}$ & $\begin{array}{l}5.91 \\
5.6-6.2\end{array}$ & $\begin{array}{l}3.40 \\
3.2-3.7\end{array}$ & $\begin{array}{l}0.576 \\
0.56-0.60\end{array}$ & $\begin{array}{l}1.797 \\
1.75-1.87\end{array}$ & $\begin{array}{l}\text { spring } \\
(n=7)\end{array}$ \\
\hline melanurum 9 , Liperi & $\begin{array}{l}6.44 \\
6.2-6.7\end{array}$ & $\begin{array}{l}6.02 \\
5.7-6.3\end{array}$ & $\begin{array}{l}3.52 \\
3.4-3.7\end{array}$ & $\begin{array}{l}0.586 \\
0.57-0.60\end{array}$ & $\begin{array}{l}1.752 \\
1.71-1.80\end{array}$ & $\begin{array}{l}\text { summer } \\
(n=5)\end{array}$ \\
\hline melanurum $q$, Janakkala & $\begin{array}{l}6.63 \\
6.3-6.8\end{array}$ & $\begin{array}{l}5.87 \\
5.7-6.0\end{array}$ & $\begin{array}{l}3.30 \\
3.1-3.4\end{array}$ & $\begin{array}{l}0.563 \\
0.54-0.58\end{array}$ & $\begin{array}{l}1.803 \\
1.75-1.83\end{array}$ & $\begin{array}{l}\text { spring } \\
(n=3)\end{array}$ \\
\hline melanurum o, Janakkala & $\begin{array}{l}6.34 \\
6.0-7.0\end{array}$ & $\begin{array}{l}5.53 \\
5.2-6.0\end{array}$ & $\begin{array}{l}3.11 \\
3.0-3.3\end{array}$ & $\begin{array}{l}0.561 \\
0.55-0.58\end{array}$ & $\begin{array}{l}1.661 \\
1.57-1.73\end{array}$ & $\begin{array}{l}\text { summer } \\
(n=25)\end{array}$ \\
\hline fusicorne P, Pälkäne & $\begin{array}{l}6.77 \\
5.9-8.0\end{array}$ & $\begin{array}{l}6.67 \\
6.0-7.5\end{array}$ & $\begin{array}{l}3.73 \\
3.4-4.2\end{array}$ & $\begin{array}{l}0.560 \\
0.53-0.59\end{array}$ & $\begin{array}{l}1.886 \\
1.76-2.00\end{array}$ & $\begin{array}{l}\text { spring } \\
(n=11)\end{array}$ \\
\hline fusicorne +, Pälkäne & $\begin{array}{l}6.92 \\
6.2-7.6\end{array}$ & $\begin{array}{l}6.60 \\
6.1-7.3\end{array}$ & $\begin{array}{l}3.61 \\
3.4-3.9\end{array}$ & $\begin{array}{l}0.547 \\
0.50-0.56\end{array}$ & $\begin{array}{l}1.813 \\
1.76-1.95\end{array}$ & $\begin{array}{l}\text { summer } \\
(n=16)\end{array}$ \\
\hline fusicorne ot, Pälkäne & $\begin{array}{l}6.54 \\
5.6-7.3\end{array}$ & $\begin{array}{l}6.12 \\
5.5-6.8\end{array}$ & $\begin{array}{l}3.39 \\
3.0-3.8\end{array}$ & $\begin{array}{l}0.556 \\
0.54-0.58\end{array}$ & $\begin{array}{l}1.808 \\
1.70-1.94\end{array}$ & $\begin{array}{l}\text { spring } \\
(n=14)\end{array}$ \\
\hline fusicorne ơ Pälkäne & $\begin{array}{l}6.43 \\
6.2-6.8\end{array}$ & $\begin{array}{l}5.58 \\
5.4-5.8\end{array}$ & $\begin{array}{l}3.17 \\
3.0-3.3\end{array}$ & $\begin{array}{l}0.567 \\
0.55-0.59\end{array}$ & $\begin{array}{l}1.700 \\
1.60-1.75\end{array}$ & $\begin{array}{l}\text { summer } \\
(n=6)\end{array}$ \\
\hline melanurum on, Liperi & $\begin{array}{l}6.14 \\
6.0-6.4\end{array}$ & $\begin{array}{l}5.71 \\
5.6-5.9\end{array}$ & $\begin{array}{l}3.27 \\
3.1-3.4\end{array}$ & $\begin{array}{l}0.573 \\
0.53-0.61\end{array}$ & $\begin{array}{l}1.740 \\
1.69-1.81\end{array}$ & $\begin{array}{l}\text { spring } \\
(\mathrm{n}=7)\end{array}$ \\
\hline melanumum ơ Liperi & $\begin{array}{l}5.80 \\
5.5-6.2\end{array}$ & $\begin{array}{l}5.27 \\
5.0-5.8\end{array}$ & $\begin{array}{l}3.07 \\
2.8-3.4\end{array}$ & $\begin{array}{l}0.583 \\
0.56-0.60\end{array}$ & $\begin{array}{l}1.703 \\
1.63-1.83\end{array}$ & $\begin{array}{l}\text { summer } \\
(n=3)\end{array}$ \\
\hline melanurum ơ, Janakkala & $\begin{array}{l}6.80 \\
6.7-6.9\end{array}$ & $\begin{array}{l}6.00 \\
5.8-6.2\end{array}$ & $\begin{array}{l}3.37 \\
3.1-3.5\end{array}$ & $\begin{array}{l}0.557 \\
0.53-0.56\end{array}$ & $\begin{array}{l}1.793 \\
1.78-1.80\end{array}$ & $\begin{array}{l}\text { spring } \\
(n=3)\end{array}$ \\
\hline melanurum $\sigma^{*}$, Janakkala & $\begin{array}{l}5.76 \\
5.6-6.0\end{array}$ & $\begin{array}{l}5.00 \\
4.7-5.2\end{array}$ & $\begin{array}{l}2.84 \\
2.7-2.9\end{array}$ & $\begin{array}{l}0.568 \\
0.56-0.58\end{array}$ & $\begin{array}{l}1.640 \\
1.58-1.69\end{array}$ & $\begin{array}{l}\text { summer } \\
(n=5)\end{array}$ \\
\hline
\end{tabular}


The length of the body was measured from the anterior frons to the apex of the abdomen, including the sawsheath of the female or hypopygium of the male. The length of the fore wing was measured from the humeral plate at the margin of the tegula to the apex of the wing (the apical part of the wing was raised with an insect pin to the same plane if needed), and the length of the costa from the same origin to the apex of the costa. The head width was measured as the distance between the lateral margins of the compound eyes. The head height was measured as the distance between the lower margin of the clypeus and the uppermost hind margin of the postocellar area. The head width at the temples was measured in dorsal view as the maximum width behind the compound eyes. The length of the female flagellum was measured as the maximum length (the basal neck-like constriction was not included), and the maximum width of flagellum was measured in lateral view, perpendicular to the longitudinal axis of the segment. The length of the male flagellum was measured as the maximum length from the basal arch of the anterolateral projection to the apex of the flagellum.

\section{Results}

The results of the measurements of Aprosthema melanurum and $A$. fusicome are presented in Tables 1-3. Table 1 shows measurements indicative of the size of the specimens. The body length and fore wing length are most commonly used in previous published studies. Two additional measurements are presented: length of costa of fore wing and the head width at eyes. They can be measured accurately and easily. The body length is the most inaccurate measurement of the four (position of head varies and extension of abdomen varies). Apical part of wing is often bowed below at the base of pterostigma. Costa is a strong straight vein. Head width can be measured most accurately. This is shown in percentual variation observed (mean $=100 \%$ ), e.g. in $A$. fusicorne females, summer generation: body from -18.4 to +9.8 , wing from -7.6 to +10.6 , costa from -5.8 to +8.0 , and head width from -2.9 to +7.6 . If head width values of different samples are compared, following results are obvious: spring generations have a slightly larger head than summer generations, females have a slightly larger head than males, and in $A$. fusicorne the mean and maximum are a little larger than in $A$. melanurum. The summer generation samples contained more or consisted entirely of reared specimens which are usually smaller than those captured in the wild; this could explain the size difference between the generations.

The head shape characters are presented in Table 2 . The spring generation has a stronger head than the summer generation: in dorsal view the temples are longer and broader behind the eyes, they broaden posteriad or are parallel or narrow only slightly. As an expression of the stronger muscles of the head the postocellar area is also longer and more convex than in summer generation, and there is a shallow furrow from near the lateral ocellus to the compound eye of the same side. In the summer generation the lateral vertex and upper lateral frons are entirely even, without any furrow. The longer postocellar area is reflected in longer head height values and larger head height/head width index values in the spring generations. The index values do not overlap or overlap only slightly. In spring generations the head width at the temples/head width at eyes index has slightly larger values than in corresponding summer generations.

The heads of several specimens are figured in dorsal view to show presence or absence of furrow on lateral vertex and form of temples (Figs 1-2). If possible, the heads of a mother sawfly and her offspring are figured. 
Table 2. Characters of head of specimens of Aprostbema melanurum (KUUG) and A. fusicome (THOHSON). Length values: mean and range in $\mathrm{mm}$.

\begin{tabular}{|c|c|c|c|c|c|c|}
\hline Species, sex, locality & $\begin{array}{l}\text { Head } \\
\text { width }\end{array}$ & $\begin{array}{l}\text { Head } \\
\text { height }\end{array}$ & $\begin{array}{l}\mathrm{HH} / \\
\mathrm{HW}\end{array}$ & $\begin{array}{l}\text { HW temple/ } \\
\text { HW }\end{array}$ & Furrow & $\begin{array}{l}\text { Generation } \\
\text { (examined) }\end{array}$ \\
\hline 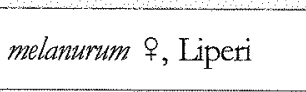 & $\begin{array}{l}1.797 \\
1.75-1.87\end{array}$ & $\begin{array}{l}1.203 \\
1.15-1.26\end{array}$ & $\begin{array}{l}0.669 \\
0.66-0.69\end{array}$ & $\begin{array}{l}0.984 \\
0.97-0.99\end{array}$ & + & $\begin{array}{l}\text { spring } \\
(\mathrm{n}=7)\end{array}$ \\
\hline melanumum 9 , Liperi & $\begin{array}{l}1.752 \\
1.71-1.80 \\
\end{array}$ & $\begin{array}{l}1.092 \\
1.05-1.12\end{array}$ & $\begin{array}{l}0.624 \\
0.61-0.64\end{array}$ & $\begin{array}{l}0.964 \\
0.96-0.97\end{array}$ & - & $\begin{array}{l}\text { summer } \\
(\mathrm{n}=5)\end{array}$ \\
\hline melanumum , Janakkala & $\begin{array}{l}1.803 \\
1.75-1.83\end{array}$ & $\begin{array}{l}1.190 \\
1.13-1.23\end{array}$ & $\begin{array}{l}0.660 \\
0.65-0.67\end{array}$ & $\begin{array}{l}0.993 \\
0.98-1.00\end{array}$ & + & $\begin{array}{l}\text { spring } \\
(n=3)\end{array}$ \\
\hline melanumum 9 , Janakkala & $\begin{array}{l}1.661 \\
1.57-1.73\end{array}$ & $\begin{array}{l}1.016 \\
0.97-1.06\end{array}$ & $\begin{array}{l}0.611 \\
0.60-0.63\end{array}$ & $\begin{array}{l}0.970 \\
0.95-0.98\end{array}$ & - & $\begin{array}{l}\text { summer } \\
(\mathrm{n}=25)\end{array}$ \\
\hline fusicorne P, Pälkäne & $\begin{array}{l}1.886 \\
1.76-2.00\end{array}$ & $\begin{array}{l}1.286 \\
1.16-1.35\end{array}$ & $\begin{array}{l}0.682 \\
0.66-0.71\end{array}$ & $\begin{array}{l}0.977 \\
0.97-0.99\end{array}$ & + & $\begin{array}{l}\text { spring } \\
(n=11)\end{array}$ \\
\hline fusicorne 오, Pälkäne & $\begin{array}{l}1.813 \\
1.76-1.95\end{array}$ & $\begin{array}{l}1.153 \\
1.09-1.24 \\
\end{array}$ & $\begin{array}{l}0.636 \\
0.61-0.66 \\
\end{array}$ & $\begin{array}{l}0.955 \\
0.93-0.97\end{array}$ & - & $\begin{array}{l}\text { summer } \\
(n=16)\end{array}$ \\
\hline fusicorne ơ, Pälkäne & \begin{tabular}{|l|}
1.808 \\
$1.70-1.94$
\end{tabular} & \begin{tabular}{|l|}
1.154 \\
$1.08-1.23$
\end{tabular} & $\begin{array}{l}0.639 \\
0.61-0.67\end{array}$ & $\begin{array}{l}0.966 \\
0.95-0.98\end{array}$ & + & $\begin{array}{l}\text { spring } \\
(\mathrm{n}=14)\end{array}$ \\
\hline fusicorne ơ, Pälkäne & $\begin{array}{l}1.700 \\
1.60-1.75\end{array}$ & $\begin{array}{l}1.052 \\
1.02-1.10\end{array}$ & $\begin{array}{l}0.620 \\
0.59-0.65\end{array}$ & $\begin{array}{l}0.960 \\
0.93-0.98\end{array}$ & - & $\begin{array}{l}\text { summer } \\
(n=6)\end{array}$ \\
\hline melanurum o, Liperi & $\begin{array}{l}1.740 \\
1.69-1.81\end{array}$ & $\begin{array}{l}1.111 \\
1.09-1.16\end{array}$ & $\begin{array}{l}0.639 \\
0.61-0.66\end{array}$ & $\begin{array}{l}0.981 \\
0.97-0.99\end{array}$ & + & $\begin{array}{l}\text { spring } \\
(n=7)\end{array}$ \\
\hline melanumum ơ, Liperi & $\begin{array}{l}1.703 \\
1.63-1.83\end{array}$ & $\begin{array}{l}1.010 \\
0.95-1.08\end{array}$ & $\begin{array}{l}0.593 \\
0.58-0.61\end{array}$ & $\begin{array}{l}0.963 \\
0.96-0.97\end{array}$ & - & $\begin{array}{l}\text { summer } \\
(n=3)\end{array}$ \\
\hline melanumm os, Janakkala & $\begin{array}{l}1.793 \\
1.78-1.80\end{array}$ & $\begin{array}{l}1.100 \\
1.08-1.12\end{array}$ & $\begin{array}{l}0.613 \\
0.60-0.63\end{array}$ & $\begin{array}{l}0.977 \\
0.97-0.98\end{array}$ & + & $\begin{array}{l}\text { spring } \\
(n=3)\end{array}$ \\
\hline melanurum o", Janakkala & $\begin{array}{l}1.640 \\
1.58-1.69\end{array}$ & $\begin{array}{l}0.938 \\
0.91-0.96\end{array}$ & $\begin{array}{l}0.574 \\
0.57-0.58\end{array}$ & $\begin{array}{l}0.958 \\
0.940 .97\end{array}$ & - & $\begin{array}{l}\text { summer } \\
(n=5)\end{array}$ \\
\hline
\end{tabular}

The characters of flagella are presented in Table 3 . The female flagellum is undivided, more or less spindle shaped, covered all over with rather short hairs. Anterior margin is slightly keeled. The flagellum of the spring generation is shorter than that of the summer generation, and in $A$. fusicorne the flagellum is shorter than in the corresponding generation of $A$. melanurum. This difference is most distinct in flagellum/head width index. The flagellum of the spring generation is thicker than that of the summer generation. Especially thick and short is the flagellum of the spring generation of $A$. fusicorne, its small length/width index does not overlap with that of the spring generation of $A$. melanurum.

The male flagellum is highly modified: it consists of a long, narrow flagellum which has dorsally short adherent hairs to the apex and of a basally attached long anterior or ventral projection. This is apically parallel with the true flagellum but differs in having short adherent hairs only basally. Both the flagellum and its projection are covered with long curved hairs on anterior surface, the lateral hairs are long and medial hairs short. The maximum length of male flagellum is longer in summer generations than in spring generations; the difference is more obvious in flagellum/head width index. 
Table 3. Characters of flagellum of specimens of Aprostbema melanurum (KIUG) and A. fusicorne (THOMSON). Length values: mean and range in $\mathrm{mm}$.

\begin{tabular}{|c|c|c|c|c|c|c|}
\hline Species, sex, locality & $\begin{array}{l}\text { Head } \\
\text { width }\end{array}$ & $\begin{array}{l}\text { Flagel- } \\
\text { lum }\end{array}$ & $\begin{array}{l}\text { Flag./ } \\
\text { HW }\end{array}$ & $\begin{array}{l}\text { Flag, } \\
\text { width }\end{array}$ & $\begin{array}{l}\text { O Flag.L// } \\
\text { W }\end{array}$ & $\begin{array}{l}\text { Generation } \\
\text { (examined) }\end{array}$ \\
\hline melanurum $\stackrel{9}{,}$ Liperi & $\begin{array}{l}1.797 \\
1.75-1.87\end{array}$ & $\begin{array}{l}1.356 \\
1.29-1.44\end{array}$ & $\begin{array}{l}0.753 \\
0.72-0.78\end{array}$ & $\begin{array}{l}0.191 \\
0.18-0.20\end{array}$ & $\begin{array}{l}7.09 \\
6.8-7.5\end{array}$ & $\begin{array}{l}\text { spring } \\
(\mathrm{n}=7)\end{array}$ \\
\hline melanurum 9 , Liperi & $\begin{array}{l}1.752 \\
1.71-1.80\end{array}$ & $\begin{array}{l}1.548 \\
1.48-1.61\end{array}$ & $\begin{array}{l}0.884 \\
0.86-0.91\end{array}$ & $\begin{array}{l}0.199 \\
0.19-0.21\end{array}$ & $\begin{array}{l}7.80 \\
7.6-8.4\end{array}$ & $\begin{array}{l}\text { summer } \\
(\mathrm{n}=5)\end{array}$ \\
\hline melanurum q, Janakkala & $\begin{array}{l}1.803 \\
1.75-1.83\end{array}$ & $\begin{array}{l}1.367 \\
1.30-1.43\end{array}$ & $\begin{array}{l}0.757 \\
0.71-0.78\end{array}$ & $\begin{array}{l}0.187 \\
0.18 \cdots 0.19\end{array}$ & $\begin{array}{l}7.30 \\
6.8-7.6 \\
\end{array}$ & $\begin{array}{l}\text { spring } \\
(\mathrm{n}=3)\end{array}$ \\
\hline melanurum 오, Janakkala & $\begin{array}{l}1.661 \\
1.57-1.73\end{array}$ & $\begin{array}{l}1.366 \\
1.22-1.52\end{array}$ & $\begin{array}{l}0.822 \\
0.78-0.88\end{array}$ & $\begin{array}{l}0.171 \\
0.15-0.19\end{array}$ & $\begin{array}{l}7.98 \\
7.5-8.6 \\
\end{array}$ & $\begin{array}{l}\text { summer } \\
(\mathrm{n}=25)\end{array}$ \\
\hline fusicorne ㅇ, Pälkäne & $\begin{array}{l}1.886 \\
1.76-2.00\end{array}$ & $\begin{array}{l}1.233 \\
1.10-1.36\end{array}$ & $\begin{array}{l}0.653 \\
0.61-0.71\end{array}$ & $\begin{array}{l}0.223 \\
0.20-0.25\end{array}$ & $\begin{array}{l}5.55 \\
5.0-5.9\end{array}$ & $\begin{array}{l}\text { spring } \\
(n=11)\end{array}$ \\
\hline fusicome P, Pälkäne & $\begin{array}{l}1.813 \\
1.76-1.95\end{array}$ & $\begin{array}{l}1.369 \\
1.28-1.47\end{array}$ & $\begin{array}{l}0.754 \\
0.72-0.80\end{array}$ & $\begin{array}{l}0.197 \\
0.17-0.22\end{array}$ & $\begin{array}{l}7.01 \\
6.2-8.1 \\
\end{array}$ & $\begin{array}{l}\text { summer } \\
(n=16)\end{array}$ \\
\hline fusicome ơ, Pälkäne & $\begin{array}{l}1.808 \\
1.70-1.94\end{array}$ & $\begin{array}{l}2.116 \\
1.88-2.45\end{array}$ & $\begin{array}{l}1.169 \\
1.09-1.26\end{array}$ & & & $\begin{array}{l}\text { spring } \\
(\mathrm{n}=14)\end{array}$ \\
\hline fusicorne ơ, Pälkäne & $\begin{array}{l}1.700 \\
1.60-1.75\end{array}$ & $\begin{array}{l}2.118 \\
1.94-2.32\end{array}$ & $\begin{array}{l}1.248 \\
1.18-1.33\end{array}$ & & & $\begin{array}{l}\text { summer } \\
(n=6)\end{array}$ \\
\hline melanurum of, Liperi & $\begin{array}{l}1.740 \\
1.69-1.81\end{array}$ & $\begin{array}{l}2.091 \\
1.99-2.15\end{array}$ & $\begin{array}{l}1.201 \\
1.16-1.25\end{array}$ & & & $\begin{array}{l}\text { spring } \\
(\mathrm{n}=7)\end{array}$ \\
\hline melanurum ơ, Liperi & $\begin{array}{l}1.703 \\
1.63-1.83\end{array}$ & $\begin{array}{l}2.327 \\
2.23-2.50\end{array}$ & $\begin{array}{l}1.367 \\
1.36-1.37\end{array}$ & & & $\begin{array}{l}\text { summer } \\
(\mathrm{n}=3)\end{array}$ \\
\hline melanurum ơ, Janakkala & $\begin{array}{l}1.793 \\
1.78-1.80\end{array}$ & $\begin{array}{l}2.223 \\
2.12-2.31\end{array}$ & $\begin{array}{l}1.240 \\
1.18-1.30\end{array}$ & & & $\begin{array}{l}\text { spring } \\
(n=3)\end{array}$ \\
\hline melanurum of, Janakkala & $\begin{array}{l}1.640 \\
1.58-1.69\end{array}$ & $\begin{array}{l}2.216 \\
2.09-2.32\end{array}$ & $\begin{array}{l}1.350 \\
1.31-1.39\end{array}$ & & & $\begin{array}{l}\text { summer } \\
(n=5)\end{array}$ \\
\hline
\end{tabular}

The lamnia of the lancets of the saws of Finnish species of Aprosthema were figured by VITTASAARI (1990: Fig. $3 \mathrm{a}-\mathrm{f}$ ). The general shape of lamnia is very similar. What is named Aprosthema melanurum (KLUG, 1814) in this paper, consisted of two species in VIITASAARI (1990): the spring generation was called A.tardum (KLUG), and the summer generation $A$. brevicorne (FALLÉN). An examination of the two female specimens of Hylotoma tarda in KLUG's collection (not syntypes but fitting the original description), and the lectotype female of Hylotoma brevicornis FALLEN revealed that these species are not conspecific with Aprosthema melanurum (see Key later). The species which is identified as A. fusicome (THOMSON, 1871) in this paper was named as two species in VIITASAARI (1990): the spring generation was correctly called A. fusicorne (THOMSON) and the summer generation $A$. bifidum. There is no specimen of Hylotoma bifida (KLUG, 1834: 244, $0^{\star}$ ) in KLUG's collection at present, and a neotype is needed to settle its identity. It is now most often regarded as a synonym of $A$. melanurum which seems a good solution to me. VIITASAARI (1990) found small differences in the details of lamnia of the spring and the summer generations, e.g. the teeth are better developed in summer generation of A. fusicome (Fig. b as A. bifida) than in spring generation (Fig. $\mathrm{f}$ : almost apical half smooth, without teeth). The base of lancet (radix) was not figured by VIITASAARI 
(1990). I studied the radix-parts of one female of each of two generations of Aprosthema melanurum from Liperi and A. fusicorne from Pälkäne. The base is modified in Aprosthema, and the most basal parts lie along the inside of the hypopygium and thus form a right angle with the tractium. Both generations of $A$. melanurum have a three-branched (trifurcate) basal part (Fig. 3a) whereas both generations of $A$. fusicorne have a bifurcate basal part (Fig. 3b).

The penis valves of Finnish species of Aprosthema were figured in VIITASAARI (1990: Fig. 5 a-f). The penis valves of the spring generation (Fig. $5 \mathrm{~d}$ : as $A$. tardum) and the summer generation (Fig. 5 a: as $A$. brevicorne; also $5 \mathrm{~b}$ and $5 \mathrm{c}$ : as $A$. friesei; these are only paler conspecific specimens) of $A$. melanurum are rather similar. The penis valves of the spring generation (Fig. $5 \mathrm{f}$ ) and the summer generation (Fig. 5 e: as $A$. bifidum) of $A$. fusicorne are similar to each other, but clearly different from those of $A$. melanurum. Thus the shape of penis valve does not correlate with the head form type at all which shows that the head form type (strong or weak) is not a character distinguishing between species. I have drawn the apical part of the penis of both species in situ (A. melanurum: Fig. 4a and A. fusicorne: Fig. 4b).

The body colour of the spring and summer forms of Aprosthema melanurum may show big difference. Females of the summer form are often paler than females of the spring form. Hind femur is mostly black in the spring, but its base can be only slightly black or it is entirely yellow in the summer. Terga 2 and 9 lose often their blackish colour in the summer generation. The apex of mesoscutellum and axillae may show reddish brown colour in summer females. The summer males of $A$. melanurum often have a pale costa and their scape and pedicel can be reddish. Similar differences in body colour can be found between the specimens of two generations of $A$. fusicorne.

The larva of Aprosthema intermedium (ZADDACH), under the name $A$. byalinopterum CONDE, was described in many details by CONDE (1934a). He also briefly described the larva of A. melanurum (KLUG). The chaetotaxy of the third abdominal segment of $A$. melanurum from Liperi is shown in Fig. 5. The anal tergum and the subanal lobe is shown in Fig. 6a-b.

The larva of A. fusicorne (THOMSON) is described here for the first time. According to KANGAS (1985), and cited by VIITASAARI (1990), it lives in colonies. This is incorrect: it is a solitary feeder, like the larva of $A$. melanurum. The wrong conclusion was based on the observation that the summer cocoons were found in small clusters on the host plant. I have examined 5 larvae from Pälkäne, prepared by Erkki $O$. Peltonen by blowing air into an empty skin in an oven. Two larvae were taken on Vicia cracca by J. Kangas, and prepared on 17.7.1962 and 7.7.1971; three larvae are from the ovipositing experiment (3/86 JK).

Description of full grown larva of $A$. fusicorne: Head width $1.48-1.59 \mathrm{~mm}$, frons width 0.62$0.67 \mathrm{~mm}$, length of body 16.6-18.9 $\mathrm{mm}$ (inflated larva). Head pale, brownish (on vertex composed of small brown maculae), coronal stripe darker brownish. Trunk green, cuticle covered with small dark granulae; longitudinal dorsomedial stripe on thoracic segments 12 and abdominal segments 6-9 composed of larger dark granulae. Spiracles brownish black, brown-winged. Head in anterior view roundish, height from anteriot margin of clypeus to topmost vertex slightly smaller $(0.97)$ than head width. Trunk cylindrical, maximal width on 
abdominal segments 3-4. Subcutaneous blackish glands with vertical openings anterior to spiracle on thoracic segment 1 , on postspiracular lobes on abdominal segments $2-8$ and on corresponding lobe on abdominal segment 9. Small prolegs on abdominal segments 2-8 near midline, those on segment 7 smaller than anterior ones, and those on segment 8 very small. Chaetotaxy: Frons 15 , clypeus $2+3$, labrum $3+3$ or $2+2$, mandible 1 , stipes 1 , palpifer 1 , second maxillar segment 1 seta. $3^{\text {rd }}$ abdominal segment with 3 dorsal annulets, dorsal setae on warts lacking granular sculpture, usually one seta per wart. Number of larger setae (seen with $100 \mathrm{x}$ magnification): annulet $1: 2$, and 1 below level of spiracle, and ventrally 2 anterior to proleg; annulet $2: 4$, and 1 near spiracle; annulet 3: 4; postspiracular lobe: 1; subspiracular area: 8 ; and surpedal area 7 setae. On anterolateral surface of proleg 3-4 setae. Caudal margin of anal tergum shown in Fig. 7a. Subanal lobe with projections shown in Fig. $7 \mathrm{~b}$.

Notes. I communicated about my first rearing and ovipositing observations in Liperi at the monthly meeting of the Entomological Society of Finland on 16 September 1994. VIITASAARI et al. (1998: 142) cited this communication but the human memory can be unreliable: the species which I observed was not $A$. fusicorne or $A$. bifidum. The latter name is wrongly mentioned also by VIITASAARI (2002: 172). Later I could examine the reported two Estonian species with the help of Mikk Heidemaa: the species which was named Aprosthema bifidum (KLUG) is $A$. fusicorne, and $A$. melanurum was misidentified as A. brevicorne (FALLÉN).

Key to species of Aprosthema treated in this paper (all species have a spring form with stronger head with shallow furrow on lateral vertex, and shorter flagellum, and a summer form with weaker head having entirely flat lateral vertex, longer flagellum and often paler colouration of the body):

1 (6) Mesoscutellum with rather erect hairs, apical and lateral margins with a hairless zone (Fig. 8). Metascutellum with hairs mostly on anterior surface, in dorsal view the hairs do not project behind the sclerite (Fig. 8).

2 (3) Female: apical 0.6 of hind tibia infuscate, hind tarsus, except base of basitarsus, infuscate. Terga 1-2 and 9 often blackish. Male: apex of penis valve with a small incisura and lateral margin strongly projecting (Fig. 4a). Larva on Latbyrus pratensis L., anal tergum of full grown larva with short medial projections. ... A. melanurum (KLUG)

3 (2) Female: at most apical 0.15 of hind tibia and apical 0.20 of hind basitarsomere infuscate, hind tarsomeres 2-3 with pale base. Terga 2 and 9 without blackish colour. Male: apex of penis valve with deep incisura, and lateral margin rounded (Fig. 4b). Anal tergum of full grown larva with long, sharp medial projections.

4(5) Fore wing strongly infuscate. Larva on Vicia cracca L................ A. fusicorne (THOMSON)

5 (4) Fore wing, except costal cell, subhyaline. Larva on Latbyrus vernus (L.) BERNH. 
6(1) Mesoscutellum with numerous hairs, which on apex and lateral margins appear quite low (no hairless area) and which are directed more parallel to surface (backwards or laterad) (Fig. 9). Metascutellum hairy on all surfaces, on posterior surface hairs project backwards (Fig. 9).

7 (8) Maxillary palpus with 6 segments (Fig. 10a). Female: hind tibia and tarsus extensively infuscate. Male: apex of penis (Fig. 11a). Larva on ?Vicia sativa L.; CONDE (1934b: as $A$. austriacum (KONOW)) found a cocoon on that plant. ................. brevicorne (FALLEN)

8 (7) Maxillary palpus with 5 segments, two apical fused (Fig. 10b). Female: only narrow apex of hind tibia and of hind tarsomeres 1-3 infuscate. Male: apex of penis (Fig. 11b). Larva on ?Latbyrus sylvestris L. (One female of the summer generation was found in southern Finland on that plant; VIITASAARI (1990) misidentified it as A. bumeratum) A. tardum (KLUG)

\section{Discussion}

The experimentally proven seasonal head dimorphism of Aprosthema melanurum is the first to be reported in the Symphyta. The head form (long, strong or short, weak) has been used in Aprosthema as an important character to separate species into two groups. So $A$. melamumum is keyed usually under two different names in the handbooks or the revisions. Often the name $A$. tardum has incorrectly been used for the long head form (KONOW 1892, ENSLIN 1917, CONDE 1934a, GUSSAKOVSKIJ 1935, ZHELOCHOVTSEV 1988, and VITTASAARI 1990). BURGgraAF-VAN NIEROP ET VAN ACHTERBERG (1990) treated the two forms of A. melanurum as conspecific, whereas SCHWARZ \& BLANK (1996) regarded them as different species but they could not confirm the difference in penis form figured in ZHELOCHOVTSEV (1988: fig. 32, 4: A. tardum; 6: A. melanurum).

In Finland the species of Aprosthema have often been misidentified which is understandable because there is no revision based on examination of the types. HELLEN (1956) separated two species from eastern Fennoscandia: a species with a strong head named $A$. tardum, including $A$. cylindricorne auct. fenn. and $A$. fusicorne, and another species with a weak head named $A$. melanurum, and including $A$. bifidum auct. fenn. The observations on the biology of A. fusicorne made in Borga (N) by A. Nordman (larvae on Vicia cracca, and the thin summer cocoons on Vicia cracca and Juniperus) were reported under $A$. melanurum by Hellén. Perhaps this is the reason why Vicia cracca is wrongly mentioned as a food plant of A. melanurum or A. tardum in ZHELOCHOVTSEV (1988) and LISTON (1995).

The British specialist on sawflies, Robert B. Benson did not succeed well in Aprosthema. In the handbook (BENSON 1951) he wrote that the single British species would run, by its colour pattern, to $A$. dalmatica (MOCSÁRY) in Enslin's key, but it does not appear to differ structurally from $A$. melanura. His $A$. melanura contains two species neither of which is A. melanurum. The male and female specimens from Hampshire, New Forest belong to A. tardum (KLUG) and the male from Berkshire, Cothill to $A$. fusicorne (all three specimens examined in coll. NHM, London). The male genitalia are clearly different. QUINLAN \& GAULD (1981) repeated the findings of Benson. BENSON (1968) wrote that in Europe 
and Turkey there are probably only two species: Aprostbema tarda and A. melamura. This is not true at all. Also the real Aprosthema melanurum (KLUG) has been found in England: I have examined a male (in coll. NHM, London) of the spring generation taken in Oxford(shire), Marston, Cherwell Meadows on 4.6.1941 by P. M. Miles. It has been studied and labelled by several entomologists: Sterictophora [!] furcata (Villers) o det. R. B. Benson 1948; Aprosthema sp. det. F. Koch 87; Aprosthema fusicorne (Thomson, 1871) det. L. Clemons 1993; Aprosthema of cf. tarda Klug det. C. v. Achterberg 1993. Three more specimens of $A$. fusicome (THOMSON) have been found in England: a female of the spring form in Souldrop, Bedfordshire on 24.6.1956 on Vicia cracca, leg. V. H. Chambers; and a female and a male of the summer generation in Chippenham Fen, Cambridgeshire, TL 650693, Malaise trap: carr at reed bed edge, 6.7.-20.7.1985 (female), 20.7.-1.8.1984 (male), leg. J. Field (all three in coll. RSMNH, Edinburgh).

I have studied much material of Aprosthema from Europe and Asia, including most of the types. The seasonal head dimorphism appears to be a regular phenomenon in the genus. This will change the taxonomy of the genus greatly. It is a pity that the rearing experiments of the species are very few. This has prevented us from a better understanding of this interesting genus. The thin, weak summer cocoons constructed on the food plant or other plant nearby appear to be characteristic for Aprosthema. To open them no strong muscles are needed. Obviously this is the reason why during evolution the head form with weak muscles (short postocellar area and short weak temples) of the summer generation has developed. The winter cocoon is in the ground and it is much thicker. Therefore strong muscles are needed when the adult emerges in the spring time. Sometimes the summer generation is passed over; this favours the view that the strong head form is the basic form.

\section{Acknowledgements}

This study would not have been possible to complete without the help of the curators of several entomological collections. I wish to thank for loan of specimens Anders Albrecht, Alexander Antropor, Stephan Blank, Roy Danielsson, Erich Diller, Fritz Gusenleitner, Bert Gustafsson, Mikk Heidemaa, Lars-Åke Janzon, Frank Koch, Martt Koponen, Manfred Kraus, Michael Maidl, Rudolf Meier, Matti Nuorteva, Martin Schwarz, Stefan Schödl, Mark Shaw, Akihiko Shinohara, David Smith, Andreas Taeger, Christine Taylor, Jukka Vauras, Matti Viitasaari, Alexey Zinovjev, and Lajos Zombori. My thanks no longer reach Jaakko K. Kangas who died on 4 March, 2003 at the age of 88 years; I dedicate this paper to the memory of my friend since 1959. Andrew Liston and Andreas Taeger critically commented the manuscript and the pictures, and Andrew Liston improved my English language.

\section{References}

BENSON, R. B. 1951: Hymenoptera 2. Symphyta. Section (a). - Handbooks for the identification of British insects 6 , part 2 (a): $1-49$.

BENSON, R. B. 1968: Hymenoptera from Turkey Symphyta. - Bulletin of the British Museum (Natural History) Entomology 22 (4): 109-207.

BurggraAf-VAN Nierop, Y. D. \& ACHTerberg, C. van 1990: De Cephidae en Argidae van Nederland (Hymenoptera). - Zoologische Bijdragen Leiden 39: 1-66.

CONDE, O. 1934a: Versuch einer Revision einiger mitteleuropäischen Aprostbema-Arten (Hymenoptera, Tent.). Folia Zoologica et Hydrobiologuca Riga 7: 20-30. 
CONDE, O. 1934b: Ostbaltische Tenthredinoidea II. - Korrespondenzblatt Naturforscher-Verein zu Riga 61: 168-198.

GuSSAKOVSKIJ, V. V. 1935: Chalastogastra (P. 1). - Faune de l'URSS Insectes Hymenoptères T. II, vol. 1: XVIII + 454 pp. [n Russian, Latin, and German]

HELLÉN, W. 1956: Mitteilungen über einigen Tenthredinoiden aus Ostfennoskandien II (Hym.). - Notulae Entomologicae, Helsingfors 35 (4) (1935): 107-122.

HUber, J. T. \& ShARKEY, M. J. 1993: Chapter 3, Structure, pp. 13-59. - In: GouleT, H. \& Huber, J. T. (eds.) Hymenoptera of the world: An identification guide to families. - Agriculture Canada, Ottawa, Ontario, vii $+668 \mathrm{pp}$.

ENSLIN, E. 1917: Die Tenthredinoidea Mitteleuropas VI. - Deutsche Entomologische Zeitschrift, Beiheft: $539-662$.

KANGAS, J. K. 1985: Pälkäneen sahapistiäisfauna 1953-1983. The sawfly fauna of the commune Pälkäne in southern Finland (Hymenoptera, Symphyta). - Pälkäne-Seuran julkaisuja 5: 1-113. [In Finnish with English summary]

KLUG, J. C. F. 1814: Die Blattwespen nach ihren Gattungen und Arten zusammengestellt. - Magazin der Gesellschaft naturforschenden Freunde zu Berlin 6: 276-310.

KLUG, J. C. F. 1834: Uebersicht der Tenthredinetae der Sammlung [des Berliner Entomologischen Museums]. - Jahrbücher der Insectenkunde, Berlin p. 223-253, Tab. II, Figs 5-10.

KONOW, F. W. 1892: Analytische Uebersicht der europäischen Arten der Tenthrediniden-Gattung Schizocera LATR. - Wiener Entomologische Zeitung 11 (1): 11-22.

Liston, A. D. 1995: Compendium of European sawflies. - Chalastos Forestry, Gottfrieding, 190 pp.

Quinlan, J. \& GAULD, I. D. 1981: Symphyta (except Tenthredinidae) Hymenoptera New edition. Handbooks for the identification of British insects 6, part 2 (a): 1-67.

SCHWARZ, M. \& BLANK, S. M. 1996: Bürsten- und Keulhornblattwespen im Bundesland Salzburg (Österreich) (Hymenoptera, Symphyta: Argidae und Cimbicidae). - Linzer biologische Beiträge 28 (2): 937-951.

THomson, C. G. 1871: Tentbredo et Sirex LIN. - Hymenoptera Scandinaviae 1: 1-342.

VIITASAARI, M. 1990: Sawflies 5. Argidae, Blasticotomidae and Cimbicidae. - University of Helsinki. Department of Agricultural and Forest Zoology. Reports 15: 1-80. [n Finnish with English summary, lectotype designations and references to the supplementary publications].

VIITASAARI, M. 2002: The suborder Symphyta of the Hymenoptera. - In: VIITASAARI, M. (ed.), Sawflies I: 11-174. Tremex Press Ltd., Helsinki. 516 pp.

VitTASAaRr, M.; HeIDEMAA, M.; NUORTEVA, M. \& ZinovjeV, A. 1998: An annotated checklist of the sawflies (Hymenoptera, Symphyta) of Estonia. - Proceedings of the Estonian Academy of Sciences Biology Ecology 47 (2): 126-147.

ZADDACH, G. 1864: Beobachtungen über die Arten der Blatt- und Holzwespen von C. G. A. BRISCHKE, erstem Lehrer am Spend- und Waisenhause zu Danzig und Dr. Gustav Zaddach, Professor in Königsberg, mitgetheilt von Zaddach. (Zweite Abhandlung). - Schriften der [Königlichen] physikalisch-ökonomischen Gesellschaft zu Königsberg, Königsberg 4 [1863]: 83-124.

ZHELOCHOVTSEV, A. N. 1988: Symphyta. - In: TOBIAS, V. I. \& ZINOVjEV, A. G. (Eds): Keys to the insects of the European part of the USSR 3. Hymenoptera 6: 7-234. Keys to the fauna of the USSR No. 158 [In Russian; English translation 1994 by Oxonian Press Pvt. Ltd., New Delhi]

\author{
Author's address: \\ VELI VIKBERG \\ Liinalammintie 11 as. 6 \\ FIN-14200 Turenki \\ Finland \\ e-mail: veli.vikberg@mail.htk.fi
}




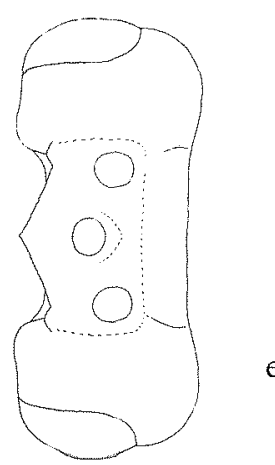

e
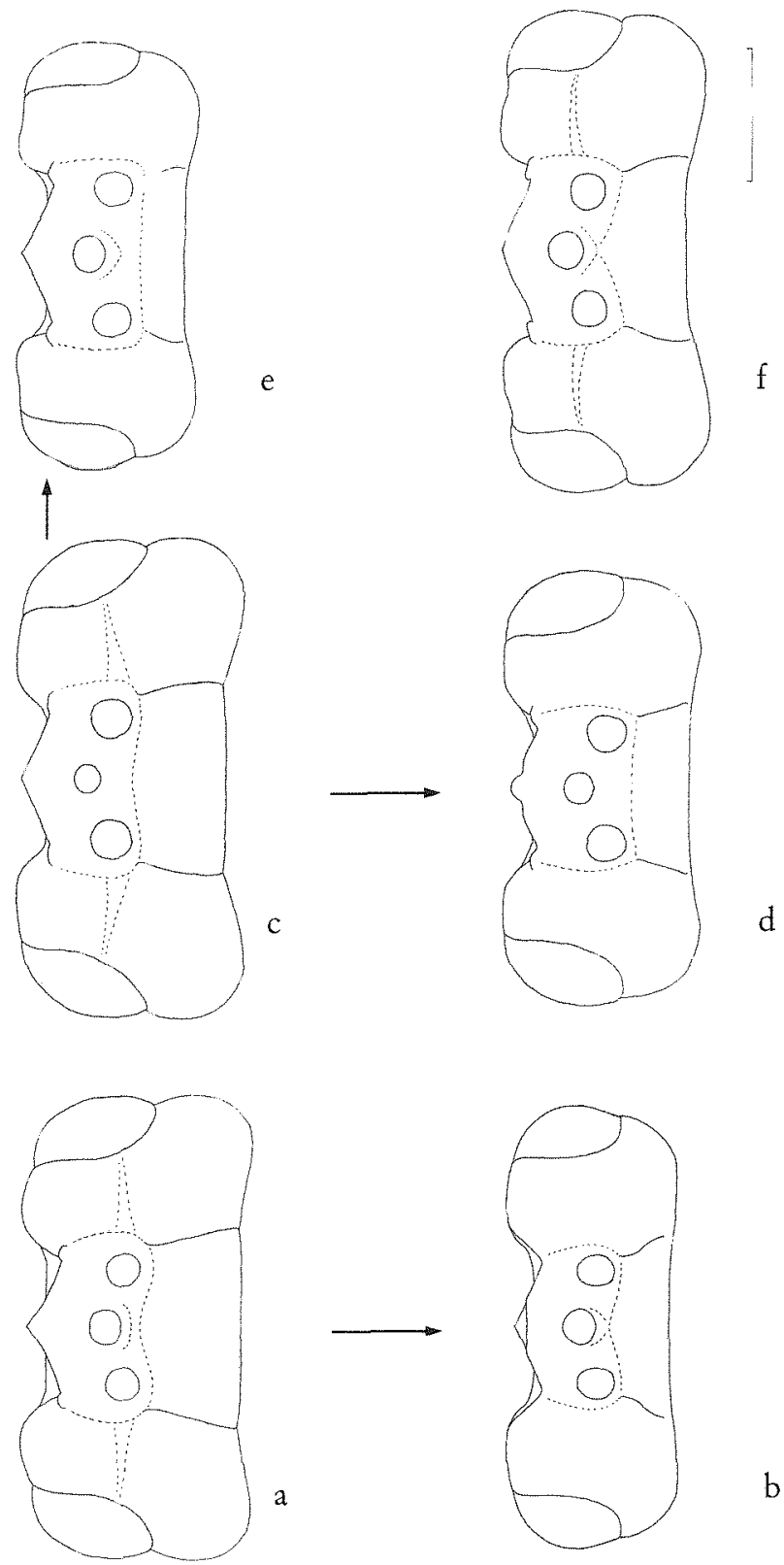

Fig. 1: Aprostbema melanumum (KLUG) from Finland, head in dorsal view. a. Liperi, spring female, mother 8/94; b. Liperi, summer male, son of a; c. Janakkala, spring female, mother $6 / 01$; d. summer female, daughter of c; e. summer male, son of c; f. Janakkala, spring male 27.5.2001. - Scale $0.5 \mathrm{~mm}$. 

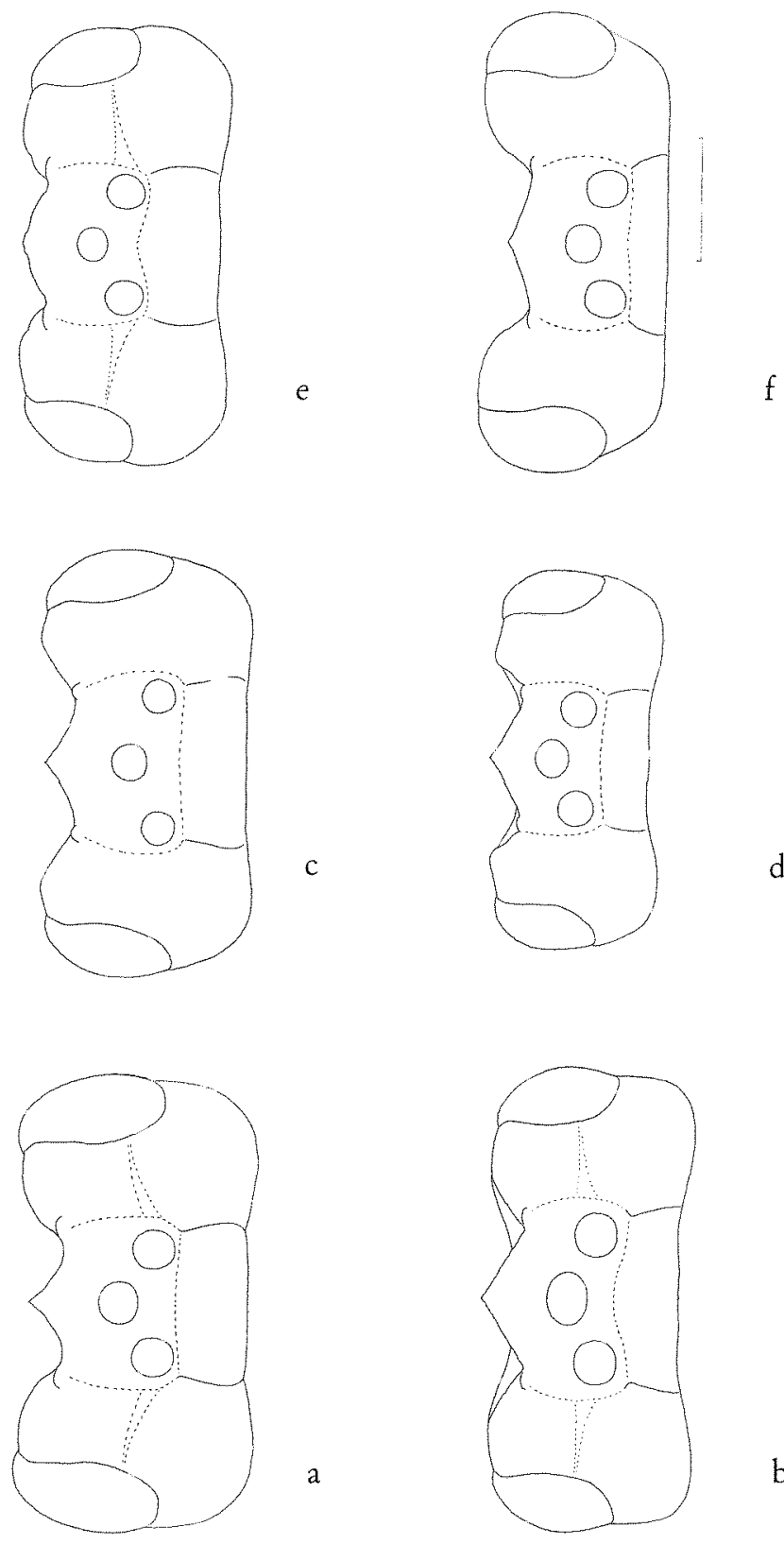

b

Fig. 2 a-d: Aprosthema fusicorne (THOMSON), from Pälkäne, Finland, and e-f: A. intermedium (ZADDACH), head in dorsal view. a. spring female, 14.6.1965; b. spring male, 17.6.1959; c. summer female, ex cocoon on Vicia cracca, 23.7.1961; d. summer male, ex cocoon on Vicia cracca, 27.7.1961; e. spring female, holotype of A. volgense GuSSAKOVSKIj; f. summer male, from Suntaschi, Gergi, Latvia, ex larva on Latbyrus vernus, em. 14.7.1935. - Scale $0.5 \mathrm{~mm}$. 


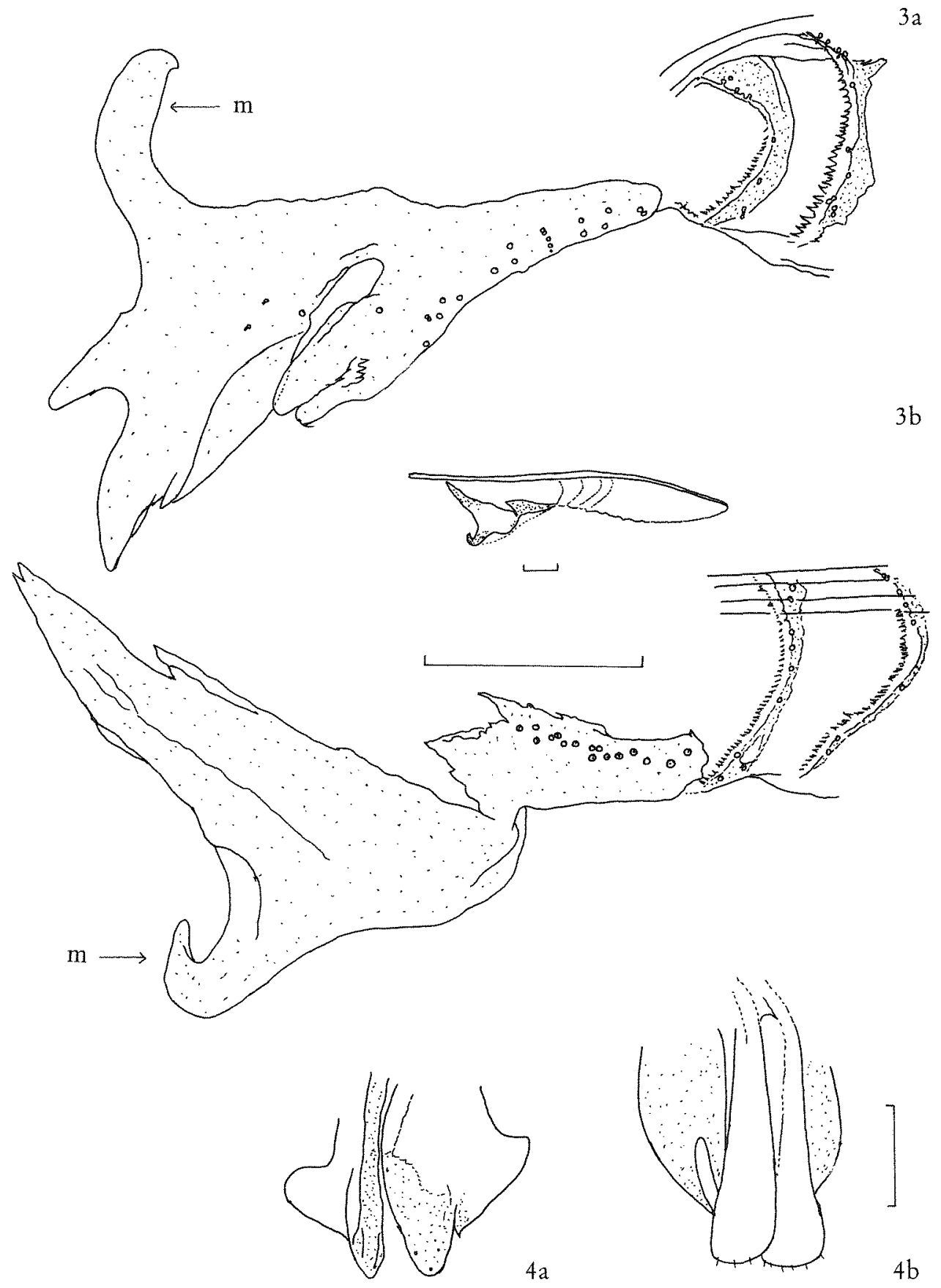

Fig. 3: Radix of lancet. a. Aprosthema melanurum (KLUG) from Liperi, 4.7.1994; b. A. fusicome (THOMSON), Pälkäne, 3.7.1962. Insert: whole lancet. - Scales $0.2 \mathrm{~mm} . \mathrm{m}=$ medial branch.

Fig. 4: Apical part of penis. a. Aprostbema melanurum (KLUG), Liperi 3.7.1994, dorsal and slightly dextrolateral view; b. A. fusicome (THOMSON), Pälkäne, 17.6.1959, dorsal and slightly sinistrolateral view. - Scale $0.2 \mathrm{~mm}$. 


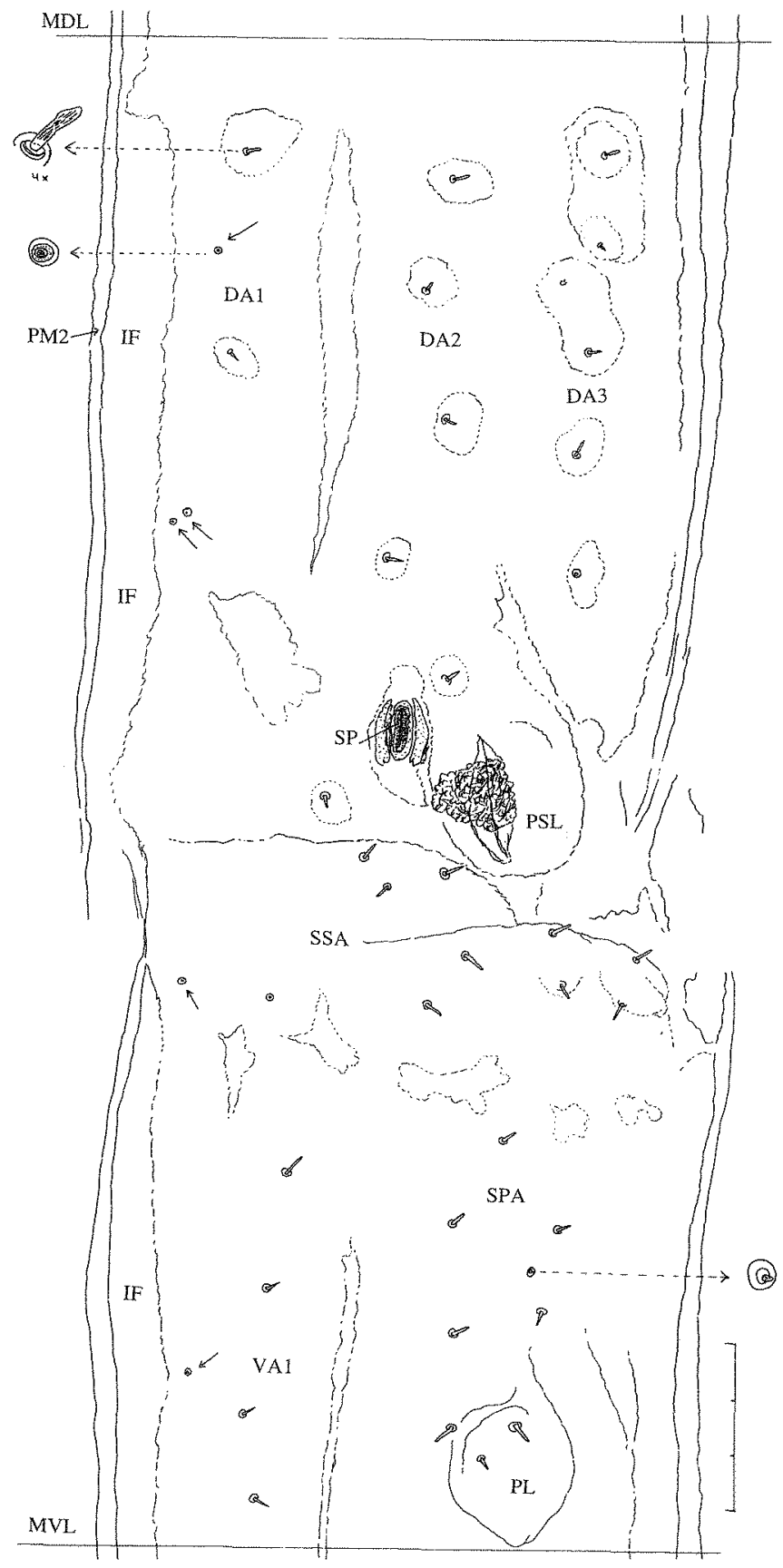

Fig. 5: Left side of $3^{\text {rd }}$ abdominal segment of full grown larva of Aprosthema melanurum (KLUG), Liperi 4.7.1994, on Latbyrus pratensis. Skin spread on slide. DA = dorsal annulet; IF = intersegmental furrow; $\mathrm{MDL}=$ middorsal line; $\mathrm{MVL}=$ midventral line; $\mathrm{PL}=$ proleg; $\mathrm{PM} 2=$ posterior margin of segment $2 ; \mathrm{PSL}$ = postspiracular lobe; $\mathrm{SP}=$ spiracle; $\mathrm{SPA}=$ surpedal area; $\mathrm{SSA}=$ subspiracular area; $\mathrm{VA}=$ ventral annulet. Atrows point to very small setae or glandubae. - Scale $0.3 \mathrm{~mm}$. 


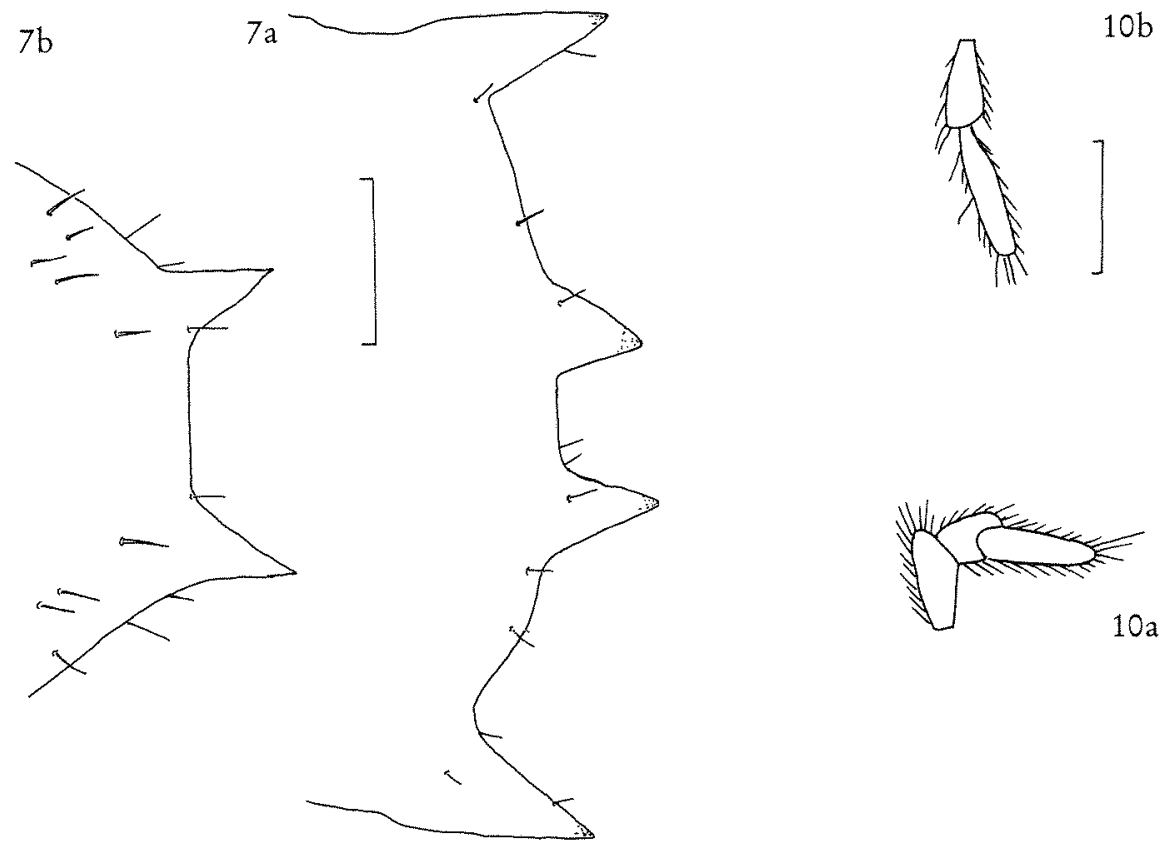

$6 \mathrm{~b}$

$6 a$
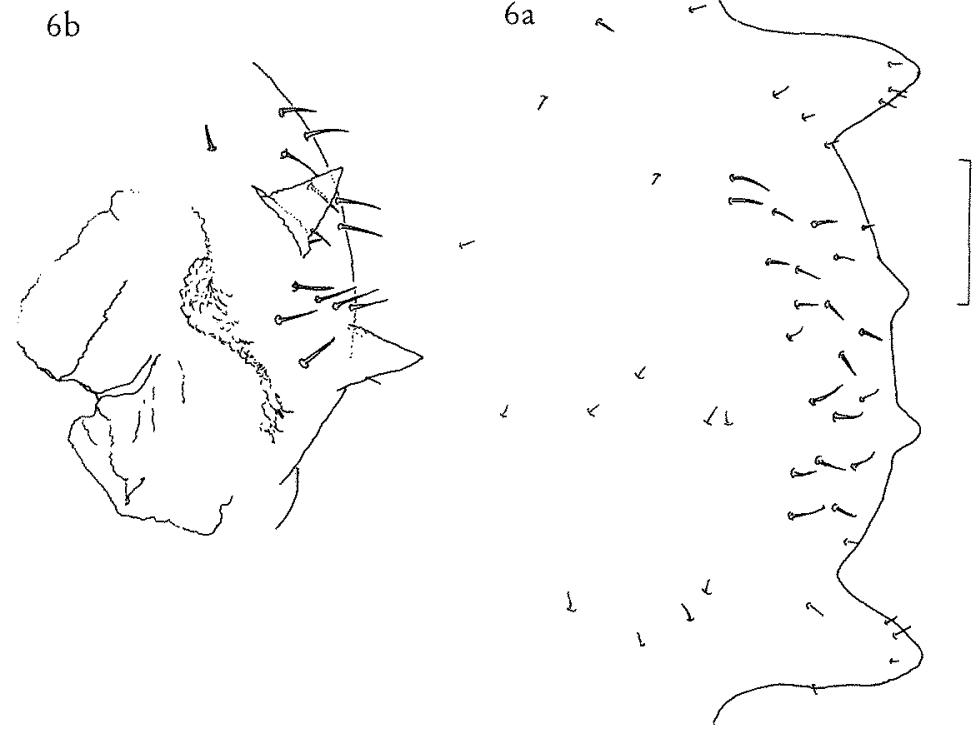

Fig. 6: Full grown larva of Aprostbema melanurum (KLUG), Liperi 4.7.1994, on Latbyrus pratensis. Skin spread on slide. a. anal tergum in dorsal view; b. subanal lobe, oblique posterior view. - Scale $0.3 \mathrm{~mm}$.

Fig. 7: Full grown larva of Aprosthema fusicorne (THOMSON), Pälkäne, Vicia cracca, ex ovo rearing 3/1986. Dry prepared larva. a. caudal margin of anal tergum in dorsal view; b. subanal lobe in dorsal view. - Scale $0.3 \mathrm{~mm}$. Fig. 10: Apical part of maxillary palpus beyond $3^{\text {rd }}$ segment. a. Aprostbema brevicorne (FALLEN), lectotype female. b. A. tardum (KLUG), male from New Forest, England, 23.7.1907. - Scale 0.2 mm. 

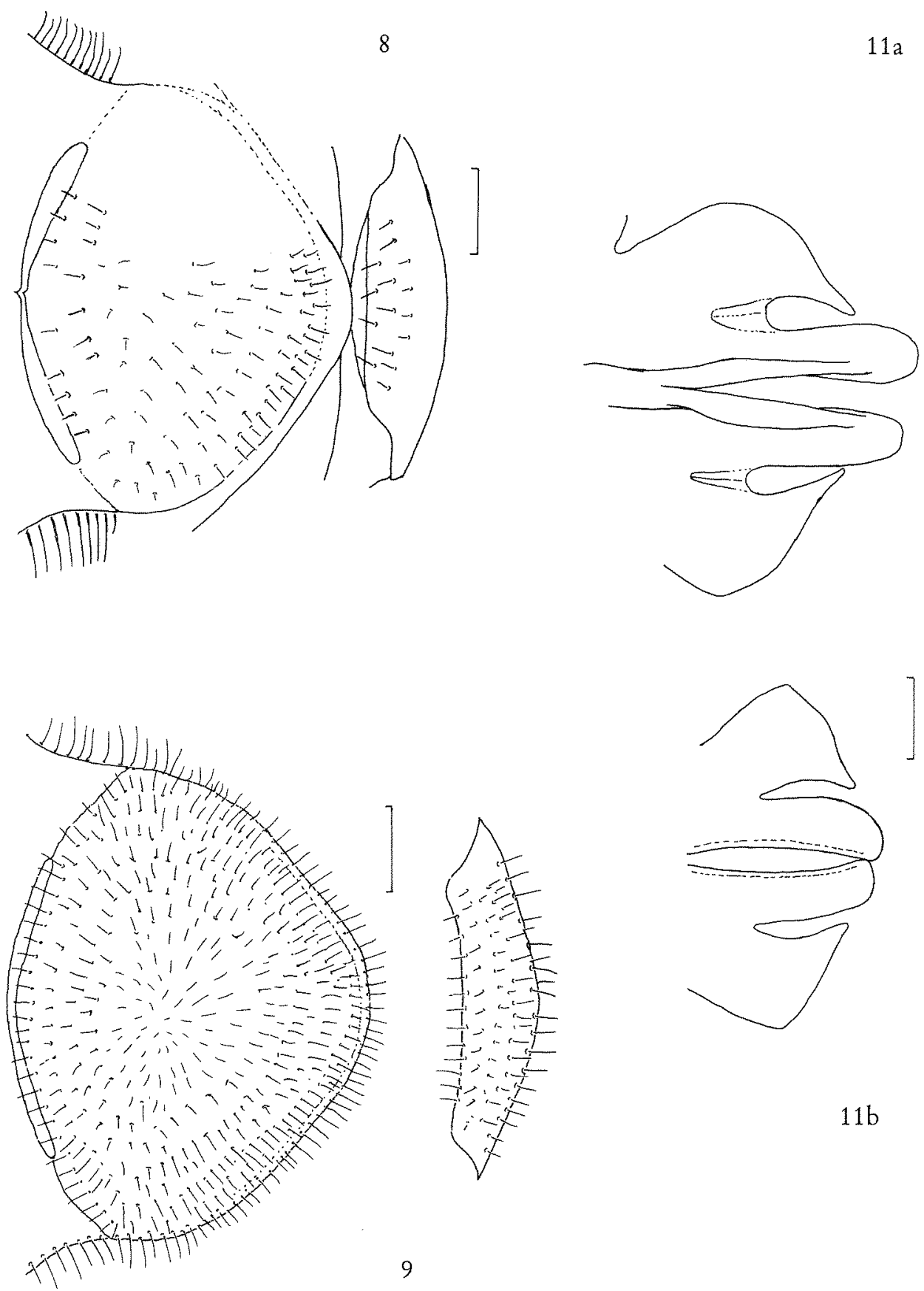

$11 \mathrm{~b}$

Fig. 8: Meso- and metascutellum of Aprosthema melanurum (KLUG), lectotype female. - Scale $0.2 \mathrm{~mm}$. Fig. 9: Meso- and metascutellum of Aprosthema brevicorne (FALLÉN), lectotype female. - Scale $0.2 \mathrm{~mm}$. Fig. 11: Apical part of penis in dorsal view. a. Aprosthema brevicome (FALLÉN), male from Sweden, Sm: Hultsjö, 3.7.1927. b. A. tardum (KLUG), male from New Forest, England, 23.7.1907. - Scale $0.1 \mathrm{~mm}$. 